\title{
STUDI PELAKSANAAN PRAKTIK KERJA INDUSTRI SIWA SMK
}

\author{
Nurifqi A. T. ${ }^{1}$, Nana Sumarna² ${ }^{2}$ Enda Permana ${ }^{3}$ \\ Departemen Pendidikan Teknik Mesin \\ Universitas Pendidikan Indonesia \\ Jl. Dr. Setiabudhi No. 207 Bandung 40154 \\ nurifqi.at@yahoo.com
}

\begin{abstract}
ABSTRAK
Penelitian ini bertujuan untuk mengetahui persiapan sekolah dan siswa sebelum pelaksanaan praktik kerja industri, pelaksanaan praktik kerja industri dilihat dari aktivitas pihak sekolah, pelaksanaan praktik kerja industri dari aktivitas siswa di industri. Penelitian ini dilaksanakan untuk mengetahui pelaksanaan praktik kerja industri Penelitian ini merupakan penelitian deskriptif kuantitatif yang bertujuan menggambarkan atau mendeskripsikan tentang pelaksanaan praktik kerja industri. Teknik pengumpulan data yang digunakan adalah angket, wawancara, dan dokumentasi. Hasil penelitian menunjukkan bahwa pada persiapan pelaksanan praktik kerja industri SMK Negeri 12 Bandung sebesar 85,65\% (kriteria sangat baik), hal tersebut ditunjukkan dengan adanya kegiatan pendidikan dasar sikap profesi yang melibatkan berbagai pihak, dimana melibatkan tentara Husen Sastranegara dalam pembentukan karakter siswa sebelum praktik kerja industri, dan adanya bekal keterampilan kejuruan siswa yang diberikan sekolah. Pelaksanaan praktik kerja industri dari SMK Negeri 12 Bandung sebesar sebesar 77,04\% (kriteria baik), didapatkan adanya kegiatan monitoring dari guru pembimbing yang baik tetapi belum optimal. Aktivitas siswa dalam praktik kerja industri sebesar 83,28\% (kriteria sangat baik), dengan siswa dapat mengaplikasikan kompetensi keahliannya. Jadi dapat disimpulkan bahwa pelaksanaan praktik kerja industri pada SMK Negeri 12 Bandung dapat dikategorikan sangat baik, seperti yang terindikasi dalam persentase sebesar $81,99 \%$.
\end{abstract}

Kata kunci: praktik kerja industri, persiapan, aktivitas, profesi.

\section{PENDAHULUAN}

Praktik kerja industri merupakan salah satu jalur pendidikan yang dilaksanakan di luar sekolah, di lembaga pelatihan atau industri. Praktik kerja industri yang dilaksanakan secara sistematis dan sinkron, antara program pendidikan di sekolah dengan berbagai program keahlian yang diperoleh melalui kegiatan bekerja langsung di dunia usaha/ dunia industri, yang dilaksanakan dengan terarah. Praktik kerja industri merupakan salah satu kegiatan pembelajaran, yang dilaksanakan oleh siswa program keahlian Konstruksi Rangka Pesawat Udara, saat menginjak kelas XI. Salah satu tujuan praktik kerja industri untuk mengenalkan dan memberi pengalaman, serta wadah dalam mengaplikaskan ilmu yang telah dipelajari di sekolah, pada dunia industri. Praktik kerja industri tepat untuk membantu para siswa dalam meningkatkan kemampuan kerja. Dampaknya pada perubahan perilaku dari aspek kognitif, keterampilan dan sikap, yang nantinya ketiga aspek tersebut dapat di aplikasikan kembali di mata pelajaran produktif kelas XII jurusan Konstruksi Rangka

\footnotetext{
${ }^{1}$ Mahasiswa Departemen Pendidikan Teknik Mesin FPTK UPI

${ }^{2}$ Dosen Departemen Pendidikan Teknik Mesin FPTK UPI

${ }^{3}$ Dosen Departemen Pendidikan Teknik Mesin FPTK UPI
} 
Pesawat Udara di SMK Negeri 12 Bandung, setelah kegiatan praktik kerja industri telah dijalani.

Tujuan praktik industri (Ratna, 2012) sebagai meningkatkan mutu dan relevansi pendidikan kejuruan, melalui peran serta institusi pasangan; menghasilkan tamatan yang memiliki pengetahuan, keterampilan, dan etos kerja, yang sesuai dengan tuntutan lapangan pekerjaan dan bekal dasar pengembangan dirinya secara berkelanjutan; dan pengalaman kerja sebagai bagian dari proses pendidikan. Sedangkan, penelitian ini bertujuan untuk mengetahui persiapan, pelaksanaan, dan aktivitas siswa dalam praktik kerja industri.

Setelah para peserta didik melaksanakan prakerin di dunia industri, diharapkan adanya peningkatan kemampuan individual pada peserta didik, memiliki motivasi kerja yang tinggi, displin, dan sikap yang professional, sesuai dengan tuntutan dunia industri. Melalui praktik industri ini, diharapkan pengalaman dan wawasan siswa tentang dunia kerja akan bertambah dan memiliki kesiapan kerja yang tinggi (Arikunto dan Jabar, 2009).

\section{METODE PENELITIAN}

Penelitian ini menggunakan metode deskriptif dengan pendekatan kuantitatif. Penelitian ini dilaksanakan di SMK Negeri 12 Bandung yang berlokasi di Jalan Pajajaran No 92 Bandung, Provinsi Jawa Barat, dengan subjek penelitian siswa kelas XII Konstruksi Rangka Pesawat Udara (KRPU) 1 dan 2 dengan jumlah siswa sebanyak 50, yang telah melaksanakan praktik kerja industri

Instrumen penelitian menggunakan metode angket, wawancara dan dokumentasi sebagai metode pengumpulan data. Angket yang digunakan adalah yang tertutup yang dianalisis menggunakan skala Likert. Pada skala Likert setiap pernyataan diajukan kepada responden dengan alternatif jawaban selalu, sering, kadang-kadang, jarang, tidak pernah. Teknik analisis data yang digunakan adalah teknik analisis deskriptif. Data yang bersifat kuantitatif diproses, sehingga diperoleh persentase.

\section{HASIL PENELITIAN}

Hasil sebaran angket pada siswa kelas XII Konstruksi Rangka Pesawat Udara SMK Negeri 12 Bandung. Setelah data didapatkan kemudian data tersebut dianalisis setiap pertanyaan. Hasil penelitian dianalisis tiap variabel (Tabel 1), sehingga tiap variabel diketahui besaran persentasenya. 
Tabel 1. Persentase tiap variabel

\begin{tabular}{|c|c|}
\hline \multicolumn{2}{|c|}{ Persentase Penyampaian Tujuan Praktik Kerja Industri } \\
\hline Jumlah jawaban dari responden $\times 100$ & Hasil Persentase sebesar $88,2 \%$ \\
\hline 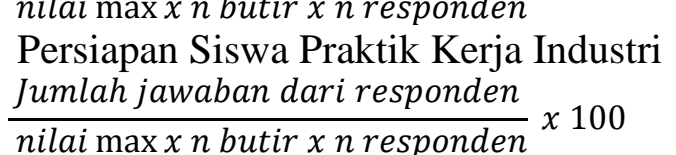 & Hasil Persentase sebesar $84,64 \%$ \\
\hline $\begin{array}{l}\text { Peran Guru Pembimbing Sekolah } \\
\frac{\text { Jumlah jawaban dari responden }}{\text { nilai max } x \text { n butir } \times \text { n responden }} \times 100\end{array}$ & Hasil Persentase sebesar $77,04 \%$ \\
\hline 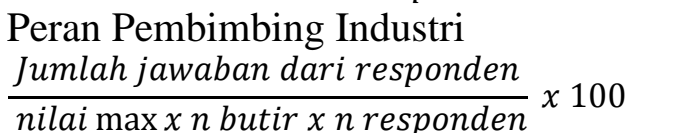 & Hasil Persentase sebesar $87,28 \%$ \\
\hline Aktivitas Siswa dalam Praktik Kerja Ind & stri \\
\hline$\frac{\text { Jumlah jawaban dari responden }}{\text { nilai } \max x n \text { butir } \times n \text { responden }} \times 100$ & Hasil Persentase sebesar $83,28 \%$ \\
\hline Dampak Setelah Melaksanakan Praktik & erja Industri \\
\hline$\frac{\text { Jumlah jawaban dari responden }}{\text { nilai } \max x n \text { butir } \times n \text { responden }} \times 100$ & Hasil Persentase $83,71 \%$ \\
\hline
\end{tabular}

Tiap indikator dikatehui presentase dan interprestasinya (Tabel 2) sebagai dasar untuk menganalisis pelaksanaan praktek industri.

Tabel 2. Hasil pelaksanaan praktik kerja industri

\begin{tabular}{clcccl}
\hline No. & \multicolumn{1}{c}{ Variabel } & $\begin{array}{c}\text { Persentase } \\
\text { Kategori } \\
\text { Skor }\end{array}$ & $\begin{array}{c}\text { Keterangan } \\
\text { Kategori } \\
\text { Skor }\end{array}$ & $\begin{array}{c}\text { Interpretasi } \\
\text { Jumlah } \\
\text { Skor }\end{array}$ & $\begin{array}{l}\text { Keterangan } \\
\text { Interpretasi } \\
\text { Skor }\end{array}$ \\
\hline 1. & $\begin{array}{l}\text { Penyampaian Tujuan } \\
\text { Praktik Kerja Industri }\end{array}$ & $94 \%$ & $\begin{array}{c}\text { Sangat } \\
\text { Baik }\end{array}$ & $88,2 \%$ & Sangat Baik \\
2. & $\begin{array}{l}\text { Persiapan Siswa dalam } \\
\text { Sangat } \\
\text { Baik }\end{array}$ & $74 \%$ & $84,64 \%$ & Sangat Baik \\
3. $\begin{array}{l}\text { Peran Gurj Pembimbing } \\
\text { Sekolah }\end{array}$ & $94 \%$ & Baik & $77,04 \%$ & Baik \\
4. & $\begin{array}{l}\text { Peran Pembimbing } \\
\text { Lapangan }\end{array}$ & $84 \%$ & $\begin{array}{c}\text { Sangat } \\
\text { Baik }\end{array}$ & $87,28 \%$ & Sangat Baik \\
5. & $\begin{array}{l}\text { Aktivitas Siswa dalam } \\
\text { Sengat } \\
\text { Baik }\end{array}$ & $78 \%$ & $83,2 \%$ & Sangat Baik \\
6. & $\begin{array}{l}\text { Aktivitas Siswa Kalam } \\
\text { Sikap Kerja }\end{array}$ & $96 \%$ & $\begin{array}{c}\text { Sangat } \\
\text { Baik }\end{array}$ & $83,87 \%$ & Sangat Baik \\
7. & $\begin{array}{l}\text { Aktivitas Siswa dalam } \\
\text { Keterampilan Kerja }\end{array}$ & $96 \%$ & Baik & $83,11 \%$ & Sangat Baik \\
8. & $\begin{array}{l}\text { Dampak Praktik Kerja } \\
\text { Industri }\end{array}$ & $94 \%$ & Baik & $83,71 \%$ & Sangat Baik \\
\hline
\end{tabular}

\section{PEMBAHASAN}

Persiapan pelaksanaan praktik kerja industri SMK Negeri 12 Bandung dilaksanakan dengan baik, dengan adanya kegiatan pendidikan dasar sikap profesi, yang melibatkan berbagai pihak, tentara Husen dalam membantu membentuk karakter siswa, pihak industri dalam memberikan informasi mengenai kegiatan praktik kerja industri, dan 
persiapan siswa didapatkan sebesar 74\% siswa mendapatkan bekal keterampilan sangat baik, yang diberikan oleh sekolah, serta dari hasil penyampaian tujuan yang dilakukan oleh pihak sekolah kepada siswa, mampu diterima dengan baik ini didapatkan dari 94\% siswa menerima penyampaian tujuan praktik kerja industri (Zulfa dan Winanti, 2013)

Peran pembimbing lapangan sangatlah berperan penting, karena pembimbing lapangan dapat memantau langsung kegiatan siswa praktikkan selama di industri. sebanyak 84\% siswa (Gambar 5) menyatakan peran pembimbing lapangan dalam kategori sangat baik, yaitu perannya yang bertanggung jawab dalam pelaksanaan, pengawasan selama kegiatan praktik kerja industri, berbanding terbalik dengan guru pembimbing sekolah dalam kegiatan monitoring tidak berjalan dengan optimal, meskipun demikian 92\% (Gambar 6) siswa menyatakan peran pembimbing sekolah dalam kategori baik, yaitu membantu dalam proses pembuatan laporan yang akan di ujiankan, oleh pihak penguji di sekolah nanti.

Aktivitas siswa kelas XII Konstruksi Rangka Pesawat Udara dalam praktik kerja industri, sebesar $78 \%$ siswa didukung dengan pengetahuan kerja yang sangat baik, ditambah sikap kerja yang sebesar 96\% siswa (Tabel 2)) dalam kategori baik, dengan adanya bantuan kegiatan pendidikan dasar sikap profesi (PDSP) yang diadakan oleh pihak sekolah, sehingga berdampak pada keterampilan kerja siswa, yang didapatkan sebesar 96\% siswa dalam kategori baik, yaitu dapat mengaplikasikan keahlian kejuruannya dengan baik di industri saat kegiatan praktik kerja industri.

\section{KESIMPULAN}

Kesimpulan penelitian dapat diuraikan, sebagai berikut: persiapan pelaksanaan praktik kerja industri sangat baik. Adanya kegiatan pendidikan dasar sikap profesi yang melibatkan berbagai pihak dan pembekalan keterampilan kepada siswa oleh pihak sekolah. Pelaksanaan praktik kerja industri dan peran guru pembimbing kategori baik. Aktivitas siswa dalam praktik kerja industri sangat baik. Pengetahuan kerja siswa memberikan kontribusi pada porsi tugas/pekerjaan yang mereka kerjakan selama praktik kerja industri. Sikap siswa sudah mendukung dengan pembekalan oleh sekolah dalam kegiatan pendidikan dasar sikap profesi (PDSP). Siswapun dapat melihat langsung sikap kerja pada saat di industri. Keterampilan kerja siswa yang didukung pengetahuan kerja akan mampu meningkatkan produktivitas dalam bekerja serta sikap yang baik, sehingga dapat bekerja dengan optimal. 


\section{DAFTAR PUSTAKA}

Arikunto, S, \& Jabar, C. S. A. (2009). Evaluasi Program Pendidikan. Jakarta: Bumi Aksara.

Ratna, S. (2012). Peran Praktik Industri dalam Menunjang Kesiapan Memasuki

Dunia Kerja Siswa Kelas XI Program Keahlian Busana SMK Karya Rini Yogyakarta. (Skripsi, Universitas Negeri Yogyakarta, 2012). [Online].

Diakses dari eprints.uny.ac.id/6905.

Zulfa, L, I \& Winanti, E, T. (2013). Kompetensi Pedagogik Guru Mata Pelajaran Menggambar Konstruksi Atap Program Keahlian Teknik Gambar Bangunan (TGB) di SMK Se-Surabaya. Pp, 1-7. 